\title{
"HÜKÜMLÜ" OLMANIN SOSYAL TEZAHÜRLERİ: SOSYAL DIŞLANMA, DAMGA VE SUÇ
}

\section{SOCIAL APPEARENCES OF BEING AN OFFENDER: SOCIAL EXCLUSION, STIGMA AND CRIME}

\author{
Meral TIMURTURKAN ${ }^{1}$, Gönül DEMEZ ${ }^{2}$, Elife KART ${ }^{3}$, Cihan ERTAN ${ }^{4}$, Selim $_{\text {CANKURTARAN }}^{5}$, \\ Salih AKTIN ${ }^{6}$
}

$\ddot{O} z$

Bu çalışma; bir suç işledikten sonraki hukuksal süreçler aşamasında yeniden topluma katılan ve "suçlu" veya "hükümlü" olarak etiketlenen bireylerin gündelik yaşam içinde karşılaştığı sorunlar ve sosyal dışlanma deneyimi üzerine bir tartışma yürütmeyi amaçlamaktadır. Hükümlü olmak, başlı başına birey ve toplum açısından sosyal uyum ve sosyal bütünleşme gibi süreçleri yeniden kurmayı ve sorgulamayı gündeme getirerek, bireyin hem özel yaşamında, hem de sosyal yaşamında keskin kopuşlar yaşamasına neden olabilmektedir. Bu durum; dışlanma, damgalanma, ötekileştirilme gibi süreçlerin yanında, bireyin sahip olduğu sosyo-kültürel ve ekonomik yaşamın bütünüyle yitirilmesini ve ceza sonrası yeniden inşa edilmesini de içermektedir. Çünkü toplumsal sapma ve suç söz konusu olduğunda, en önemli sorunların başında toplumsal soyutlanma, dışarda birakllma, sosyal dışlanma ve damgalama gibi ayrışmaya neden olacak durumlar gelmektedir. Bu bağlamda çalı̧̧ma; özellikle bu kavramlar üzerinden yürütülen tartışmalardan yola çıkarak, mahkûmiyet durumunun toplumsal ilişskilere nasıl yansıdı̆̆ını, aile yaşamının nasıl etkilendiğini, bireyin bu süreçte yaşadı̆̆ temel sorunların neler olduğunu, yüz yüze yapılan anket çalışmasından elde edilen verilerin sonuçları üzerinden tartışmayı amaçlamaktadır. Çalışma söz konusu bu süreçleri "denetimli serbestlik" örneği üzerinden irdelemeyi hedeflemektedir.

Anahtar Kelimler: Damga, Sosyal Dışlanma, Suç, Ceza, Denetimli Serbestlik

\section{Abstract}

This study aims to argue and focus on the social exclusion experiences and obstacles of individuals who have rejoined the society after juridical processes and are being labelled as "criminal" or "convicted". Being

1 Yrd. Doç. Dr., Mehmet Akif Ersoy Üniversitesi, meralgulkaya@gmail.com

2 Doç. Dr., Akdeniz Üniversitesi, gonuldemez@gmail.com

3Yrd. Doç. Dr., Akdeniz Üniversitesi, elifeekart@gmail.com

4Yrd. Doç. Dr., Düzce Üniversitesi, cihanertan1@gmail.com

5Uzman Sosyolog, Antalya Denetimli Serbestlik Müdürlüğü, selim.cankurtaran@adalet.gov.tr

6 Yüksek Lisans Öğrencisi, Akdeniz Üniversitesi, Sosyoloji Bölümü, salihaktin@hotmail.com 
offender may result in a sharp break in both private and social life of an individuals, bringing into question the reconstitution of some processes such as socialization and social integration in terms of both society and individual. This situation involves, along with the processes of exclusion, labelling, othering, also the loss of the social-cultural and economic life of the individual and as well as the reconstruction of it. When it comes to social deviance and crime, processes such as social exclusion, social isolation and labelling, which lead to disintegration, occur as prominent issues. This study, in this context, based on the arguments over these concepts, seeks to argue, by means of the results of the survey conducted with the people under probation, how being an offender influences his/her relations of family and social; what fundamental problems the individual as an offender.

Keywords: Stigma, Social Exlusion, Crime, Punishment, Probation

\section{GİRIȘ}

Damga ve sosyal dışlanma gibi kavramlar sosyal dezavantajlılık/ayrışma tartışmalarına yeni bir boyut kazandırarak, bireyi toplumsal süreç ve ilişkilerden ayıran mekanizmaların neler olduğunu açığa çıkarmamız açısından önem kazanmaktadır. Söz konusu kavramlar toplumda belli nedenlerden dolayı dışarda bırakılmış; ekonomik, politik, kültürel, sosyal ve mekânsal gibi çok farklı alanlarda gerek söylemsel, gerekse toplumsal eylem boyutunda dezavantaja sahip bireyleri veya grupları tanımlamak için yaygın olarak kullanılmaktadır. Bireyi toplumsal bütünün dışına iten nedenler; toplumdan topluma ve kültürden kültüre farkl1lık gösterebilmekte buna bağlı soyutlanmanın, cezalandırmanın ve ötekileştirmenin yöntemleri de değişebilmektedir. Bu çalışma kapsamında ele alınan ve herhangi bir nedenden dolayı hüküm giymiş ve suçlu olarak etiketlenen bireyler de sosyal dışlanma süreçlerinin farklı boyutlarıyla yüzleşebilmektedir. Bu bağlamda suç genellikle evrensel boyutta belli yaptırımların ve cezalandırmaların konusu olmuş ve toplumsal bütünlüğü bozan bir düşünce olarak görülmüştür. Dolaysıyla suç işleyenler toplumsal damga ve dışlanmanın farklı görünümleriyle karşılaşabilmekte, toplumsal bütünlük açısından bir tehdit olarak görülebilmektedir. Örneğin mahkûm olarak damgalanan bireyin potansiyel suçlu olarak görülmesi, onun farklı bir statü grubuna yerleştirilmesine de neden olmaktadır. $\mathrm{Bu}$ bağlamda suç işlemek veya suçlu olmak; toplumsal normlardan uzaklaşmak, toplumsal düzeni bozmak ve sapkın davranışta bulunmak gibi tanımlarla ifade edilmiş ve kolektif düşüncenin veya sosyal bütünleşmenin önünde bir engel teşkil ettiği düşünülmüştür. Her ne kadar sosyal dışlanma yeni bir kavram olarak literatürdeki yerini alsa da, onun karşıtı olarak tanımlanan sosyal bütünleşme veya sosyal içerilme klasik sosyoloji kuramları içinde değişen toplumsal dinamikler ve bu süreçte ortaya çıkan sorunları analiz etmek için kullanılan temel kavramlardan biri olmuştur. Özellikle klasik sosyoloji kuramları içinde sapma, anomi, sosyal dayanışma gibi kavramları açıklayıp bunları toplumsal bütünleşme ve düzen ile ilişkilendiren Durkheim (1995; 1960), Merton (1938) gibi düşünürlerin çalışmaları konuyu daha bütünlüklü anlamamız açısından yol gösterici olmaktadır. Durkheim'ın anomi kavramı çeşitli nedenlerle toplumu bir arada tutan değerlerin anlam yitirmesi, içinin boşalması ve yaptırım gücünün azalması durumlarını ifade eder. Durkheim suçu, anomik durumlarda ortaya çıkıp her toplumda ortaya çıkabilecek ve "normal" kabul edilebilecek bir davranış olarak görmenin yanı sıra, belli sınırların aşıldığı durumları ise patolojik bir durum olarak değerlendirmektedir.

Suç; bir yandan toplumsal bağı, dayanışmayı güçlendirmekte öte yandan suç işleyen için toplumsal çözülme, toplumla bütünleşmenin sağlanamaması anlamını da taşımaktadır. Bu düşünceden hareketle; toplumu 
korumak, bütünleşmeyi sağlamak ve damgalanmayı azaltmak için çeşitli yöntem ve kurallar geliştirilmiş, "baskıc1", "hizaya getirici", "kapatmaya dayanan" katı sistemler yerine bireyi toplumla bütünleştirecek yeni sistemler ve politikalar geliştirilmiştir. Toplum ve birey yararına odaklanan bu politikalar; ağır ve bedensel cezalarla suçlu bireyi toplum dişına itmek yerine toplum içinde bireyi yeniden toplumla bütünleştirerek rehabilite etmenin uzun vadede daha işlevsel olduğu düşüncesine odaklanmıştır. Böylece damgalanan birey "iyileştirilme" ve "normalleştirme" amacıyla çeşitli uygulamaların da öznesi haline gelmekte ve dolaysıyla toplumsal sapma engellenmeye çalışılmaktadır. Bu bağlamda değişen toplumsal dinamikler ışı̆̆ında suç ve cezalandırma sistemi de değişmiş, baskıcı hukuk sistemi yerine, "tamir”" edici (eski hale dönüştürücü) hukuk sistemi hâkim olmuştur. Bu dönüşen hukuk anlayışında; değişen ve işlenen bir suçun karşıllığı intikam almak veya katı cezalandırmak yerine, suçtan veya eylemden önceki koşullarının yeniden yaratılmasını sağlama amacı taşmaktadır (Pope, 2008: 80). Denetimli serbestlik uygulaması ise baskıcı cezalandırma sistemine bir alternatif olarak, suçluyu topluma kazandırmayı amaçlayan, bir başka ifade ile suçlunun koşullarını iyileştirmeye yönelik yeni bir hukuki ve toplumsal sistem olarak ortaya çıkmıştır.

Değişen toplumsal dinamikler işığında cezalandırma sistemleri dönüşüme uğrasa da "suçlu" ya olan bakış açısı değişmemiş, toplum açısından potansiyel tehlike olarak görülmeye devam etmiştir. Bu bakış açısı birey için, çoğunlukla geride bırakmak istedikleri bir damgalanmış, (Goffman, 1963) bozulmuş ve örselenmiş kimliğin varlı̆̆ı olarak da düşünülebilir (Kirkwood ve McNeill, 2015: 520). Bu bağlamda bu çalışma; dışlanma, damgalanma ve suç ile ilgili kuramsal ve kavramsal tartışma eşliğinde mahkûmlar, suçlular ve toplumun dışına itilenler arasında nasıl bir ilişki olduğunu, sahadan elde edilen verilere dayanarak açığa çıkarmayı amaçlamaktadır. Bu amaç doğrultusunda; denetimli serbestlikten faydalanan bireylerin, yakın (akraba, arkadaş gibi, sosyal çevre) ilişkilerinde, ekonomik yaşamlarında ve toplumsal ilişkilerinde ne gibi dönüşümlerin yaşandığı ve bireylerin bundan nasıl etkilendiği, sosyal dışlanmayı nasıl deneyimledikleri tartışmaya açılacaktır.

\section{DIŞLANMA VE DAMGALANMA}

Toplumsal sapma, suç ve yaptırımlar söz konusu olduğunda; sosyal dışlanma ve damgalanma, toplumdan soyutlanma, gibi toplumsal ayrışmaya yol açan temel süreçleri irdelemek önemli bir konu olarak karşımıza çıkmaktadır. Goffman (1963) damgalanmayı toplumsal kabul görme engeli olan kişilerin temsiliyeti üzerinden tanımlayarak, damgalanan bireylerin nasıl dezavantajlı grubu oluşturduğunu tartışır. Çünkü bireyin sahip olduğu nitelikler ile toplumsal değerler arasında bir uyuşmazlık çıktığı zaman, damga/damgalama süreçleri ortaya çıkmakta ve bu ise damgalanan bireyler açısından sorunlu, istenmeyen bir durumu ifade etmektedir. Birey bu dezavantajlı konumuyla sosyal ilişki ağları içerisinde daha az kabul görmekte ve daha az istenilir olmaktadır. $\mathrm{Bu}$ bağlamda damgalama türlerinden bahsetmek, suç ve mahkumiyet durumunu da bu kategori altında incelemek gerekmektedir.

Goffman'a göre (1963: 10) Yunanlılar, işaret edenin tuhaf ve kötü ahlaki durumuyla ilgili bir şeyleri ifşa etmek ve tasarlanmış beden işaretlerine dikkat çekmek için damga kavramını oluşturmuşlardır. Bu işaretler, bedende kesik ya da yanık şeklinde olup, taşıyıcısının bir köle, bir suçlu ya da bir hain olduğunu doğrudan ilan etmekteydi. Bu damgalar ve damgalanan kişilerin; özellikle kamusal alanlarda kendisinden sakınılan lekelenmiş veya kirletilmiş olarak görülmesine neden olmaktaydı. Bugün söz konusu kavram, orijinal anlamında 
kullanılmakta, fakat utancın bedensel belirginliğinden çok, utancın kendisine uygulanmaktadır. Bununla birlikte günümüzde ayıbın, utancın çok farklı türlerinden bahsetmek ve dolayısıyla suçlu olarak damgalanmayı bunlardan biri olarak ele almak gerekmektedir. Çünkü günümüzde Goffman (1963: 13) "bedensel iğrenme”, "bireysel karakterin kusurları" ve "1rk, millet kabile ve din” işaretleri olmak üzere üç farklı damgalama tipini kategorize eder. Bunlardan ilkinde, bedenin hor görülmesi ve aşağılanması söz konusudur - çeşitli fiziksel bozukluklar buna örnektir. Daha sonra zayıf irade, baskın ve doğal olmayan tutkular, tehlikeli ve katı inançlar ve sahtekârlık olarak algılanan bireysel özelliklere işaret eden damgalar söz konusudur. Bu damgalar; örneğin akı1 hastalığı, tutukluluk, bağımlılık, alkolizm, eşcinsellik, işsizlik, suç, intihar girişimleri ve radikal politik davranış gibi bilinen bir kayıttan ortaya çıkmaktadır. Son olarak, ırk, ulus ve din gibi alanları içeren kabile damgasından bahsedilir: Bunlar, nesiller yoluyla aktarılabilen damgalardır ve bir ailenin bütün üyelerini eşit olarak kirletirler. Suç ise daha çok kişisel karakterden iğrenmenin bir boyutunu oluşturur. Bu bağlamda damgalanma aynı zamanda "bozulma" kavramına da gönderme de bulunur. Stiker'in (2011: 227-229) aktardığına göre bozulma kavramının öncüsü olan Morel, tiroit bezleri zayıf çalışan ve çoğunlukla guatrlı kişilerden ya da psikiyatrik hastalığı olanlardan hareketle bozulmuşlar kategorisi yapar. Bu kategori aynı zamanda hasta ve kusursuz olmayan bireylere göndermede bulunur. Bozulmuşlar, toplum içinde normal olmayan bir grubu oluşturmakta ve hatta çoğu zaman tehlikeli olarak algılanmaktadır. Alkolikler, suçlular, bedensel bozuklukları olanlar, kısa boylular, şişmanlar, beyaz ırkın dışında kalan diğer bozulanlar da bu gruba dâhil edilebilmektedir. Bozulma düşüncesi "kusursuz" bir insan anlayışından veya ortalama tipten uzaklaşma ve dolaysıyla düşkünlük olarak algılanmaktadır. Bu durumdaki bir birey dışlanmış olmakla birlikte ötekiliğin dezavantajlı öğeleriyle baş etme durumuyla da karşı karşıya kalmaktadır. Hastalık yüzünden "bozulan” ya da “düşkünleşen” birinin tedavi edilmesi gerektiği, herhangi bir kusur yüzünden düşkünleşen birine ise yardım edilmesi veya bir suçlunun cezalandırılması gerektiği düşüncesi bu kavrayışla birlikte ortaya çıkan düşüncelerdir. Bozulmuşlar, Goffman'da olduğu gibi toplumda farklı nedenlerden dolayı damgalanan ve ötekileştirilen grubu oluşturmaktadır. Bu bireyler toplumsal düzeni bozan, normalin dışında olan "marjinal” bireyler olarak tanımlanmakta, formel veya enformel ilişki ağında yaptırımların hedefi olabilmektedir. Bu yaptırmalar süreci bazen bireyi örselediği gibi bazen de damganın yol açtığı olumsuz niteliği ortadan kaldırmaya yönelik bir çabayı da gündeme getirmektedir. Goffman (1963) bireyin, damgalanmaya kendi niteliklerinin yol açtığını düşünerek; bu niteliğini ortadan kaldırma veya iyileştirme yönüne girerek tepki verebildiğini savunmaktadır. Örneğin fiziki olarak deformasyona uğramış birinin plastik cerrahi müdahale için bıçak altına yatması, kör birinin gözü için tedavi görmesi, okuma- yazma bilmeyen birinin yeniden eğitim almaya çalışması, suçlu bir bireyin yardımları kabul etmesi gibi başarısızlığının nedeni olarak gördüğü şeyi doğrudan ortadan kaldırmaya çalışabilir. Bu anlamda Goffman (1963) damganın bireyler arasında ortaya çıkan iletişim ve etkileşim anlarında birbirlerine olan tutum ve davranışlarında belirleyici olduğunu ifade etmektedir. İliştirilen damgalar aracılığıyla bireyler karşılıklı bir tanımlama sürecine girmekte ve kim oldukları, ne yaptıkları, toplumsal statüleri ve buna benzer bir takım özellikler temelinde birbirlerini sınıflandırmaktadır. Bu süreç Becker'in (2013) "Hariciler” çalışmasında olduğu gibi karş1lıklı ayrışmayı doğurabilecek bir süreci içerir. Çünkü toplumsal düzeni ya da belli kuralları ihlal eden kişi harici olarak görülebilirken, kuralı ihlal eden kişi bu sefer de kendisini yargılayanların ya da onların ait olduğu grubu harici olarak düşünebilir. Karşılıklı bir ilişkiye dayanan bu süreç, sosyal dışlanma/sosyal içerilme ve yeniden sosyalleşme süreçlerini anlamamız açısından önemlidir. Goffman (1961) bu bağlamda, yeniden sosyalleşmeyi bireyin herhangi bir nedenle sosyal rollerinde meydana gelen keskin kopuşlar sonucu oluşan durumda sosyal 
rollerini yeniden inşa etme süreci olarak tanımlar. Örneğin, mâhkum olma durumu, suç, işsizlik, dışlanma, boşanma, dul kalma, damgalanmaya neden olacak bir hastalık ya da akıl hastalığı gibi bireyin mevcut sosyal rollerini (bazen devamlı ama bazen geçici olarak) kökten değiştiren durumlarda bireyin yeniden topluma entegre olması sürecini içeren yeni bir kimlik tanımlanması ve onarımı süreci söz konusudur. Bu noktada sosyal içerilmenin karşıtı olarak ele alınan sosyal dışlanma kavramı, suçlu olarak damgalanan bireyin toplumsal yaşamın farklı alanlarında karşılaşacağı veya karşılaştı̆̆ sorunları anlamamız açısında anahtar bir kavram olarak karşımıza çıkmaktadır.

Sosyal dişlanma, topluma kabul edilme ve toplumla bütünleşmeyi ifade eden sosyal içerilmenin (social inclusion) karşıtı olarak ele alınmakta; sosyal bağların birey ve toplum arasında kültürel ve ahlaki açıdan kopması olarak tanımlanmaktadır (De Haan, 2000: 27). Çünkü toplumsal düzen ve toplumsal bütünleşme kuramcıları, toplumun birbirine bağlı ve uyumlu bir bütünü oluşturan parçalardan oluştuğunu ve bunun ise ahlaki düzeni, uyumu sağladığını savunmaktadır. Sosyal dışlanma kavramı ise bütünleşmenin tam tersi olarak bireyin veya grubun bu ahlaki kurallardan (düzenden) kopması anlamına gelmekte ve dinamik bir sürece işaret etmektedir. 1960'lı yıllarda Fransa da tartışılmaya başlanan dışlanma kavramı, politikacılar, akademisyenler, aktivistler ve gazeteciler tarafından yoksulluğa ideolojik ve üstü kapalı bir şekilde referansta bulunmak için kullanılmıştır. Ancak kavram ekonomik krizlerle birlikte daha yaygın tartı̧ıılmaya başlanmış ve özellikle 1980'lerde Fransa'da patlak veren politik ve ekonomik krizden sonra dezavantajlı grupları tanımlamak için tekrar gündeme gelmiştir (Silver, 1994a: 532). Fransa'da Chirac hükümeti döneminde sosyal işlerden sorumlu devlet bakanı; Fransa'da 10 kişiden birinin dışlanmaya maruz kaldığına dikkat çekerek, dışlanma kavramının; mental ve fiziksel engelli, intihara eğilimli, yaşı hastalar, istismara uğrayan çocuklar, madde bağımlıları, yalnız ebeveynler, aile içi sorunu olanlar, marjinal ve sosyal anlamda uyumsuz bireylere işaret ettiğini vurgulamış ve kavramı ilk kez bu anlamda kullanmıştır. Bu dönemde refah devletinde ortaya çıkan sosyal ve ekonomik krizler, yaşanan sosyal ve siyasal gerilimler kavramın Fransa'da popüler olmasına neden olmuştur (Silver 1994a: 532). Tartışmanın çıkış noktasını yoksulluğun kavramsal olarak yeniden gündeme gelmesi ve yoksulluğa ilişkin sorunlar oluştururken, daha sonra tartışmanın çerçevesi ve kullanım alanı genişlemiş, farklı grupların maruz kaldıkları toplumsal ilişki biçimlerini tanımlamak için ele alınmaya başlanmıştır (Silver; Miller, 2003; Silver, 1994a; Silver, 1994b, Sapancal1, 2005; De Haan, 2000; Atkinson, 1998, Peace, 2001) Bununla birlikte dışlanma kavramı; çoğu zaman sınıf altı, yoksulluk, eşitsizlik, yabancılaşma, irtibatsızlık, yoksunluk, marjinallik, bütünleşememe gibi kavramları ifade etmek için de kullanılmaktadır (Sapancalı, 2005). Bu bağlamda kavramın tanımı ve işaret ettiği toplumsal ilişki biçimi çeşitlenmiş, tartışma alanı genişlemiştir. Dolaysıyla sosyal dışlanma politik, toplumsal süreçlerle ilgili çok boyutlu bir kavram olup, tanımlanması güç ama aynı zamanda farklı kanyakların yoksunluğuna göndermede bulunan bir kavramdır (Sapancal1, 2005: 54). Bu yoksunluk türü toplumdan topluma ve koşullara göre değişkenlik göstererek, genel olarak yaşam kaynaklarından, güvenceden, daimi-istihdamdan, gelirden, mülkiyetten, barınmadan, en temel veya yaygın tüketim seviyesinden, eğitimden, kültürel sermayeden, refah devletinin sağladığı imkânlardan, vatandaşlık veya hukukta eşitlik ilkesinden, demokratik katılım süreçlerinden, kamusal ürün ve hizmetlerden, ulustan, baskın ırktan veya cinsiyet eşitliğinden, aile ve sosyal ilişkilerden, tedaviden yoksun olmayı veya dışlanmayı kapsayabilir (Silver, 1994a: 541, Peace, 2001: 22, De Haan, 2000: 26). 
Sosyal dışlanmaya ilişkin yürütülen tartışmalarda en önemli noktalardan biri, her geçen gün dışlanmanın tanımının, kapsamının genişlemesi olduğu açıkça söylenebilir. Yoksulluğun tanımlanması ve marjinal olarak görülmesiyle başlayan tartışma çok farklı özelliklere sahip grupları tanımlamaya kadar uzanmıştır. Bu anlamda sosyal dışlanma kavramı: Uzun süreli veya tekrar eden işsizlik, istikrarsız ve vasıfsız işlerde ya da güvencesiz işlerde çalışanlar, düşük gelirliler ve yoksullar; vasıfsız, okuma yazma bilmeyen ve okulu terk edenler; zihinsel ve fiziksel kusuru olanlar, engelliler; madde bağımlıları; suça kaydı olanlar, çocuk suçlular, mahkûmlar; yalnız yaşayan ebeveynler; problemli ailede büyüyen veya istismara uğrayan çocuklar; kadınlar; özellikle yeterli eğitime veya iş deneyimine sahip olmayan gençler; yabancılar, mülteciler ve göçmenler; ırksal, dini ve etnik azınlıklar; kadınlar; politik hakkını kaybedenler; sosyal yardım alanlar; ihtiyaçları olduğu halde sosyal yardım için yetersiz bulananlar; kötü yerlerde yaşayanlar ve itibarsız komşusu olanlar (mekânsal dışlanmaya maruz kalanlar); tüketim seviyeleri düşük olan ve asgari geçim sınırında olanlar (açlık, evsizlik ); boş zaman veya diğer pratikleri tüketenler (uyuşturucu alkol bağımlılık, suç işleme, kılık kıyafet konuşması kötü olanlar); damgalanıp veya sapkın olarak etiketlenenler; yaşam standartları ailesinin altında olanlar ve aşağıya doğru sosyal mobiliteye sahip olanlar; marjinal veya gereksiz görülenler; aile veya arkadaş çevresinden sosyal olarak soyutlananları tanımlamak için kullanılan geniş kapsamlı bir kavramdır (Silver, 1994b: 9). Buradan hareketle, sosyal dışlanmanın hem nedeni hem de sonucu olarak ortaya çıkabilecek en önemli durumlardan birinin de suç olgusu olduğu söylenebilir.

\section{DAMGALAMA VE SUÇ İLIŞKISİ}

Suç, sapma, sapkınlık gibi bireyi “damgalayan” ve "etiketleyen” kavramlar, birey toplum etkileşimi bağlamında ikili anlamlara sahiptir. Bu alandaki temel sorgulama; kim, kimi neye dayanarak suçlu, sapkın, olarak tanımlamaktadır? Aynı zamanda bu tür damgalanmaya maruz kalanların kendilerini damgalayanlarla kurdukları ilişkiyi açığa çıkarmak ve tartışmak da önemlidir. Goffman (1963) ve Becker (2013) çalışmalarında; damgalanan ve “dışarıda bırakılanları” kapsayan süreçleri tanımlamaya, anlamlandırmaya çalışmışlardır. Suçu toplumsal olarak anlayabilmek için işe, söz konusu toplumsal yapıda suça ve suçluya yüklenen anlamları sorgulamakla başlamışlardır. Bu çerçevede etiketlenme ve damgalanmaya neden olan tüm toplumsal durumları anlama yolunu seçmişlerdir. Suç ise bu süreçlerden sadece biridir. Yani suç ve sonrasında söz konusu olan cezalandırmayı/ toplumdan soyutlamayı, disipline etmeyi ve yeniden topluma kazandırmayı içeren süreçleri tam olarak anlamlandırabilmek için toplumsal etkileşim içinde gündelik yaşamda yeniden üretilen bu kavramları, diğerleriyle birlikte ele almak gerekmektedir.

Yavuz (2016) kapatma ve hapis cezasının tarihsel sürecini anlattığı çalışmasında; “...çoğunluğu her türlü keyfiliğin, zulmün, işkencenin, insan onuru ve haysiyetini ayaklar altına alan uygulamaların beşiği haline gelmişti" diyerek durumu özetlemekte ve kapatma sonrasında da, "hapishaneden kurtulan mahkûmların işkencesi, salıverilmelerinden sonra da hatta hayatlarının sonuna kadar devam ettiğini ifade etmektedir. Çünkü "suçlu" ve "eski bir mâhkum” olarak "tehlikeli” bir kişi olduklarını belgeleyen "sarı kâğıtları" olmaksızın hayatlarını sürdürmeleri mümkün olmuyordu ki, buna da zaten hayat denilemezdi”. Söz konusu dönemde yani suçlu olarak kapatılma ve sonrasında, "damgalanma”, suçlu olarak konumlandırılma birey için telafi edilemez bir duruma dönüşüyordu. Suçlu olarak damgalanmak, başka suçlara bulaşmayı beraberinde getiriyordu. Zira bir kez suç işledikten sonra bireyin diğerleriyle ilişkilerinde önceki sosyal konumu ve kimliği, yerini yeni kimliğe (suçlu 
kimliğine) bırakır. Ünal'ın (2012) Becker ve Lemert' in konu ile ilgili düşüncelerinden aktardığına göre; suçlu kimliği anahtar kimlik haline gelen damgalanmış birey için, cezasını tamamlamış olsa bile bu kimliği ön plana çıkar ve topluma yeniden uyum sağlaması güçleşir, yeniden toplumsal bütünleşme süreci zorlaşır ve tekrar suç işleme olasıllğı artar. Bu konuda doğrudan suç ve damgalama süreçleri arasındaki ilişkiyi irdeleyen ve bu süreci sapma kavramı üzerinden açıklayan Lemert 'e (1969) göre; suçun ilk ortaya çıkışı birincil sapmayı oluştururken, bu süreçte oluşan toplumsal tutumlar ikincil sapmaya giden bir sürecin zeminini hazırlamaktadır. Örneğin yaptırımlar sonucu suçlu olarak etiketlenen birey, çeşitli nedenlerden dolayı (toplumla bütünleşememe, soyutlanma, dışlanma, düşmanlık beslemek, sosyal haklara erişememe gibi) tekrar suça yönelebilir veya toplumdan kendini soyutlayabilir. Bu süreç zaten var olan toplumsal ayrışmayı derinleştirebilmekte veya ayrışmayı ortaya çıkarmakta, aynı zamanda basit gibi görünen toplumsal tutumların aslında birey ve onun toplumla olan ilişkisini nasıl etkilediğini bize göstermektedir. Çünkü toplum, bireyleri kategorileştirmenin araçlarını ve bu kategorilerin her birinin üyeleri için olağan ve doğal olduğu düşünülen tamamlayıcı özellikleri tesis eder. Bir yabancıyla karşılaştığımızda ilk olarak dış görünüşleri, söz konusu kişinin kategorisi ve nitelikleri onun 'sosyal kimliğini' öngörmemize olanak tanır Goffman'a göre (1963: 11-14) bazen bir düşmanlığı ya da kini, sosyal sınıf gibi diğer farklılıklar temelinde rasyonelleştirerek, kişinin kalitesizliğini açıklayacak bir ideoloji ve temsil ettiği tehlike için sebep inşa ederiz. Gündelik söylemimizde bir metafor ve betimleme kaynağı olarak, orijinal anlamı hakkında düşünmeksizin bireylere (sakat, suçlu, azıll, tehlikeli) belirli damga kavramlarını kullanırız. Bu bağlamda hükümlü veya suçlu olarak damgalanmak, bir takım yoksunluklara ve yaptırımlara maruz kalmak bireyin hayatında keskin dönüşümlere neden olabilmektedir. Gerek hapis cezası alarak kapatılmadan sonra topluma yeniden katılmaya çalışmak, gerekse hükümlü olarak ceza alıp denetimli serbestlik yükümlülüklerine doğrudan katılmak damgalanma, dışlanma ve suçlu olarak tanımlanmaya neden olmaktadır. Başlı başına hükümlü etiketini taşımak; birey ve toplum açısından sosyal uyum ve sosyal içerilme gibi süreçleri yeniden kurmayı ve sorgulamayı gündeme getirir. Birey hem özel yaşamında, hem de sosyal yaşamda keskin kopuşlar yaşayabilir. Bu süreç; dışlanma, damgalanma, ötekileştirilme gibi süreçlerin yanında, bireyin sahip olduğu sosyo-kültürel ve ekonomik yaşamın bütünüyle yitirilmesini de neden olabilmektedir. Bu düşünceden hareketle, genel kamusal eğilimin hükümlüyü, itibarsız, güvenilmeyen, suçlu, dürüst olamayan, korkulacak ve tehlikeli kişi olarak tanımlama yönünde olduğu söylenebilir. Bireyin resmi ceza alması ve onun potansiyel suçlu olarak görülmesi; damgalanma düzeylerini artırmakta ve işgücü piyasasına girmesini sosyal yaşama dahil olmasını zorlaştırarak bütün toplumsal ilişkilerini yeniden örgütlemesine neden olmaktadır (Young, 1999; Harding: 2003, LeBel 2008). Bu aynı zamanda onun fiili toplumsal kimliği ile varsayılan toplumsal kimliği arasındaki uyuşmazlığa göndermede bulunur.

Goffman'a göre (1963) kişinin gerçekte dâhil olduğu kategoriler ve sahip olduğu sıfatlar onun fiili toplumsal kimliğine işaret ederken, bizim varsayımlarımızdan yola çıkarak kullandığımız kimi potansiyel sıfatlar, yakıştırmalar, değerlendirmeler ise varsayılan bir toplumsal kimliğe işaret eder. Benzer şekilde suçlu bireylere karşı kullanılan, sıfatlar bu kimlikler arası uyuşmazlığın iyi bir örneğini oluştur. Sosyal statüsü, gerçekte karakteri ne olursa olsun, itibarsız, güvenilmeyen, tehlikeli damgası yiyen bireyler tam bu uyuşmazlığın kesiştiği noktada yer alır. Bu uyuşmazlı̆̆ın farkına varıldığında veya açık bir şekilde bir uyuşmazlık söz konusu ise bireyin toplumsal kimliği örselenmekte, birey kendini toplumdan koparma eğilimi içine girerek, itibarsızlaştı̆̆ bir dünyayla başa çıkmaya da çalışmaktadır. Bu anlamda bireyin yeni bir döneme girdiği, yeniden 
inşa süreci yaşadığı söylenebilir. Suçlu olarak damgalanmak, yeniden sosyalleşme, yeniden toplum ile entegre olma sürecini beraberinde getirmekte ve birey, benlik algısını ve kişisel kimliğini yeniden kurma süreci yaşamaktadır (Goffman,1961; Becker, 2013). Tanımı ve kapsamı içinden çıktığı topluma göre belirlense de, normalin ve olmayanın çerçevesini toplumların iç dinamikleri belirler. Dolayısıyla hangi davranışın suç, sapkın ve anormal olduğunu ve nasıl damgalanacağını bireyin ya da davranışın kendisi değil içinden çıktığı toplum belirler (Goffman, 1963). Söz konusu değerlerin anlam kaybına uğraması, içinin boşalması bireyin toplumsal bütünleşmesini sekteye uğratacağı için aykırı davranan ya da genel geçer ölçülerin dışında olan birey dışlanır, damgalanır ve soyutlanır. Böylece caydırıcı önlemler olarak cezalar devreye girer. Dolayısıyla cezalandırma sistemleri, toplumsal yapılarla birlikte söz konusu toplumun ihtiyaçlarına göre yeniden düzenlenir. Birey bu süreçte, sosyal olarak belirlenmiş, tanımlanmış rollerini, bireysel benlik algısını ve toplumsal kimliğini yeniden inşa etmek durumunda kalır. Bu anlamda Becker'in (2013) ifadesi ile hariciler (outsiders); toplumsal değerler ve algılar aracılı̆̆ıla tanımlanır. Genellikle hariciler dışarıda bırakılmayı kendilerinin değil toplumsal düzenin ve toplumsal yargıların sonucu olarak görmekte ve kendilerini, kurban, suça itilmiş olarak algılamaktadır. Yine Becker, suçun bir eylemden çok toplumsal algılamalardan kaynaklanan tanımlamalarla suç olarak görüldüğünü ifade eder. Schneider ve Mckim'in (2003) yaptı̆̆ bir araştırmaya göre denetimli serbestlik sürecindeki bireyler birincil olarak işverenler, kolluk kuvvetleri ve toplum tarafından damgalamaya maruz kalmaktadır. Aynı çalışmaya göre örneklemin yarısı işverenlerin kendilerine negatif bir tutum içinde olduğunu ifade etmiştir. Normal olmayan hatta "sapan" olarak kabul edilen bireyler, toplumun dışına itilerek toplumsal baskının, ötekileştirmenin ve ayrımcılığın sadece söylemsel düzeyi ile değil aynı zamanda somut eylemleri ile karşılaşmaktadır. Çünkü damgalı bir kişinin tam insan olmadığına inanılır ve bu varsayım temelinde kişinin yaşam şanslarını zayıflatma yoluyla ayrımcılık uygulanır.

\section{YÖNTEM VE KAPSAM}

$\mathrm{Bu}$ çalışma denetimli serbestlik uygulaması aşamasındaki hükümlü bireyin toplumsal, ailevi ve ekonomik alandaki ilişkilerine odaklanarak; damgalanma, sosyal dışlanma veya sosyal içerilme deneyimi üzerinde durmayı amaçlamaktadır. Bu çerçevede çalışma, Antalya Denetimli Serbestlik Müdürlüğü’nde 20142016 yılları arasında 2560 kişi ile gerçekleştirilen, denetimli serbestlik altındaki bireylerin yeniden sosyalleşme ve toplumsal bütünleşme süreçlerinin analiz edildiği ve TÜBİTAK tarafından desteklenen 114K569'nolu, "Yeniden Sosyalleşme ve Toplumsal Bütünleşme Süreçleri: Denetimli Serbestlik Altındaki Bireyler Örneğì" başlıklı projenin sosyal dışlanma, damgalanma ve suç ile ilgili verileri üzerinden tartışılmaktadır. Çalışmanın örneklemi seçilirken; yaş, cinsiyet, eğitim, suç türü gibi ayrımlara gidilmeden ulaşılan tüm bireyler araştırmaya dâhil edilmiştir. Antalya Denetimli Serbestlik Müdürlüğü'nde farklı gruplara 14 günde bir yapılan toplam 10 grup çalışmasına katılan ve bu grup çalışmasının 4. aşamasında olan bireylerle anketler uygulanmaya başlanmıştır. Bu bağlamda çalışma; çoktan seçmeli yapılandırılmış sorulardan oluşan anketin Antalya Denetimli Serbestlik Müdürlüğü'nde gerçekleştirilmesine ve uygulamadan elde edilen verilerin SPSS programına girilerek analiz edilmesine dayanmaktadır. Her soru kendi içinde değerlendirilmiştir. Ayrıca bazı ilişkilerin ortaya çıkarılması için çapraz tablolar yapılmış, sorular ve seçenekler birbiriyle ilişkilendirilerek anlamlandırılmış ve yorumlanmıştır. Sorular demografik veriler ile suç türü, suç geçmişi ile ilişkilendirilerek; damgalanma, sosyal dışlanma kavramlarına odaklanarak, suçu kesinleşmiş ve hüküm giymiş bireyin sosyal, ekonomik ve kültürel yaşam içinde var olma/olamama biçimleri irdelenmektedir. 


\section{VERİLERIN DEĞERLENDİRMESİ}

\subsection{Demografik Özellikler}

Bir suçtan mahkûm olmuş ve söz konusu çalışma kapsamına alınmış denetimli serbestlik altındaki bireylerin cinsiyet dağılım oranı değerlendirildiğinde; \%93.4'ünü erkekler ve \% 6.6'sını da kadınlar oluşturmaktadır. Bu oranlar toplumsal cinsiyet ve suç ilişkisini yeniden gözden geçirmemizi sağlayarak, kadın ve erkeğin kamusal alanda nasıl ve ne kadar temsil edildiğine ilişkin tartışmaları da beraberinde getirmektedir. Sosyal yaşamdan dışlanan, özellikle siyasette, çalışma yaşamında ve eğitimde yeterince yer almayan ve temsil edilmeyen kadınlar diğer toplumsal ilişki ağlarının içine de girememektedir. Bu ilişki ağları; ataerkil bir toplumsal yapının yansıması olarak görülerek, günümüz ataerkil toplumlarında suç ve erkeklik bağlantısının güçlü olduğu iddia edilmektedir (Bengtsson, 2016; Krienert, 2003).

Örneklemin en önemli özelliklerinden biri de yaş dağılım oranıdır. 25 ve yaş altı \% 30.1, 26-30; \%19.2, 31-35; \%14.7, 36-40; \%13.2 ve 41 yaş üstü \%22.8'dir. Genç mahkûmların; denetimli serbestlikten faydalananlar arasında proje örnekleminin büyük bir bölümünü oluşturduğu dikkat çekmektedir. Çalışmanın saha gözlemlerine ve diğer kategorilerdeki değerlendirmelere dayanarak genç suçluluğunda büyük oranda madde bağımlılığının söz konusu olduğu açıkça söylenebilir.

Özellikle 25 yaş ve altı söz konusu olduğunda, madde bağımlılığından dolayı denetimli serbestlikte bulunanların oranı artmakta ve yaşla birlikte madde bağımlılığından denetimli serbestlikte bulunma oranı azalmaktadır. Denetimli serbestlikten yararlanan mahkûmların büyük çoğunluğunun eğitim durumunun düşük olduğu görülmektedir. En büyük oranı ilköğretim mezunları oluşturmaktadır (\%59.5). Yaş grupları dikkate alındığında ilkokul ve ortaokul mezunlarının toplamını bir kategori olarak ele alıp değerlendirdiğimizde genç yaş oranı daha da büyümektedir. Genç nüfus oranının yüksek olmasının yanında öğrenim durumuna göre suçluluk kategorileri birlikte değerlendirildiğinde, örneklemin yarıdan fazlasının genç olduğu dikkat çekmektedir. Bu oran lise mezunlarında \%27.9, üniversite mezunlarında \%10.1'dir. Çoğunluğun ilköğretim ve lise düzeyinde eğitime sahip olması, eğitim çağındaki gençlerde suçluluk ya da suça yönelme durumunun ön plana çıktığ1 gözlenmektedir. Eğitimin bireyin toplum içindeki konumunu belirlemede, ekonomik güç ve statü sağlamada önemli bir değişken olduğu göz önünde bulundurulduğunda sosyal dışlanmanın karşıtı sosyal içerilmenin sağlanmasında, özellikle toplumsal değerlerin ve normların içselleştirilmesinde ve değerlerin yeniden üretilmesinde önemli bir kurum olduğu söylenebilir. Stewart ve Stewart '1n(1993) genç hükümlülerle yaptığı bir araştırmaya göre, çoğunluğunun düşük gelirli olduğu, sosyal fonlardan destek aldığı, borçlu ve yoksul olduğu ve bunların \% 64'nin işsiz olduğu gözlemlenmiştir. Sahip olduğu sosyal ve ekonomik koşullardan dolayı dezavantajlı grubu oluşturan ve sosyal dışlanmanın farklı formlarıyla karşı karşıya gelen bu genç bireyler; aynı zamanda "hükümlü" veya "suçlu” olarak etiketlenmenin yarattığı sorunlarla da baş etmek zorunda kalmaktadır. Aynı çalışmanın sonuçlarına göre örneklemin yüzde 80'inin okulu terk etmek zorunda kaldığı ve eğitimini sürdürmede güçlük yaşadığı ortaya çıkmıştır. Bu sonuçlar en temel haklardan biri olan eğitim hakkına sahip olamayan bireylerin, vatandaşlık bilinci oluşturmada, bunu geliştirmede ve aidiyet hissetmede sorun yaşadığını ya da yaşayacağını ortaya koymaktadır. Sadece ekonomik dışlanmaya değil aynı zamanda mahkûmiyet durumundan dolayı sosyal ve kültürel koşullardan yoksun kalarak, faklı dışlanma ve damgalanma deneyimine maruz kalınmaktadır. Bu ise neden-sonuç ilişkisi içinde sürekli kendini yenileyerek bir kısır döngünün ortaya 
çıkmasını da sağlamaktadır. Çeşitli alanlardan yoksun kalmak veya bırakılmak yeni yoksunlukların da zeminini hazırlayarak dezavantajlı olmanın farklı biçimlerini yaratmaktadır

Örneklem kapsamında genç nüfus oranının fazla olduğu bilgisi, medeni durum ve çocuk sayısına ilişkin de bize fikir vermektedir. Örneklemin \%43.9'u evli iken, \% 44.9'u bekâr ve \%11. 2'si boşanmıştır. Örneklemin içinde toplam \%43.08'i çocuk sahibi olup bunlar içinde \%28 bir çocuklu, \% 36.7 iki çocuklu olup geri kalanlar 3 ve üstüdür. Bu demografik verilerin; bireyin yaşadığı ekonomik, sosyal ve kültürel koşulların neler olduğunu ve bu bağlamda sosyal dışlanma, damgalanma ve sosyal içerilme deneyimini anlamada önemli açılımlara ulaşılmasını sağlamada etkili olduğu düşünülmektedir.

\subsection{Suçu Üreten Koşullar ve Suç Türleri}

Çalışma kapsamında suç türleri kategorize edildiğinde ve oranlara bakıldığında madde bağımlılı̆̆ hükümlülerin işledikleri suç oranları arasında $\% 46.5$ ile en yüksek değer olarak ortaya çıkmıştır. Bu oranı takiben \%15.5 ile adam yaralama, \%11.5 hırsızlık, \%5.6, sahtecilik, \% 5.0 yağma (gasp), \%3.6 dolandırıcılık, adam öldürmeye teşebbüs \%3.1, adam öldürme \% 2.3 izlemektedir. Bu veriler demografik özelliklerle birlikte düşünüldüğünde madde bağımlılığına dayanan ve eğitim çağındaki genç suçluluğu oranının oldukça yüksek olduğu görülmektedir. Madde bağımlılığı, sosyal dışlanmanın hem nedeni, hem de dışlanmanın sonucunda ortaya çıkan bir durum olarak görülebilmekte ve bireyin içinde yaşadığı sosyal-kültürel çevre ile açıklanabilmektedir. Yürütülen tartışmalar ve yapılan çalışmalar özellikle dezavantajlı grubun üyeleri, uygun aile koşulları olmayan ve ailesinde herhangi birinin madde bağımlısı olan, eğitim firsatlarına erişemeyen, okulda yeterince başarılı olamayan veya erkenden ayrılmak zorunda kalan gençlerin madde bağımlısı olma ve dolaysıyla suç işleme eğiliminin yüksek olduğunu ortaya koymuştur (Bancroft \&Wilson, vd., 2004, European Monitoring Centre for Drugs and Drug Addiction report, 2008). 25 yaş altı suçluluk oranının madde bağımlılı̆̆ı kategorisinde yüksek olması bu durumun modern ötesi günümüz kent toplumuna özgü olduğu düşüncesini güçlendirmektedir. Anomi ve yabancılaşma kavramlarının modern sanayi toplumlarını daha çok ifade eder olması bu nedenledir. Üretim sürecinin her an ikame edilebilir bireylerine dönüşmek, yabancılaşmanın bir boyutunu oluşturur. Yabancılaşma, insanın kendi emeği tarafından yaratılan şeyin yine aynı insana onu köleleştiren yabancı bir öz olarak, ona hükmeden bir durum olarak geri dönme sürecidir (Tolan, 1981: 179). Bu süreç aynı zamanda sosyal dışlanmayı besleyen, bireyin toplumla bütünleşmesini sağlayan ve bireyin kendi geleceğini oluşturmasında firsatların tam olarak erişimini engelleyen temel gereksinmelerden yoksun kalmasına neden olan ve bireyin toplumla olan ilişkisinin çözülmesi, kopması, siyasal, ekonomik ve sosyal yurttaşlık haklarından yoksun olma/bırakılma süreçlerine de neden olabilmektedir (Sapancal1, 2005: 53).

Suça yönelten nedenleri ortaya koyan verilere bakıldığında; her bir değişkenin hem sosyal dışlanmayı besleyecek hem de sosyal dışlanmayı, bireyin bütün yaşam alanlarına yayacak nitelikte olduğunu söylemek mümkündür. 


\begin{tabular}{lcc}
\hline Suça Yönelten Nedenler & $\mathrm{n}$ & $\%$ \\
\hline Maddi sıkıntılar & 516 & 22.0 \\
Şiddet, dayak, istismar & 67 & 2.9 \\
Namus davası & 64 & 2.7 \\
Madde bağımlılığı & 387 & 16.5 \\
Aile, arkadaş çevresi & 983 & 41.9 \\
Diğer & 635 & 27.1 \\
\hline
\end{tabular}

Farklı sorular bağlamında yeniden ele alındığı ve tartışıldığı dikkate alınırsa; özellikle aile, arkadaş çevresinin suça yönelten nedenler arasında en yüksek oranı göstermesi (\%41.9) sosyal içerilme açısından dikkatin hangi boyutlara çekilmesi gerektiği konusunda önemli bir bilgi vermektedir. Bu oranı takiben açık bir şekilde \% 27.1 ile maddi sıkıntılar izlemesi aynı zamanda bireyin sosyalleşme sürecinin en temel zeminini oluşturan yakın çevrenin, suç üreten bir zemin olması ve bunun maddi sıkıntılarla eklemlenmesi, mahkûmlar açısından hem iş piyasasından dışlanma ya da dışlanma riski ile karşı karşıya gelme, hem de aslında bütün sosyal alanların dışında kalma anlamına geldiği söylenebilir. Farklı sorular bağlamında, (işini nasıl bulduğu, mahkumiyet süresi boyunca ne tür destekler aldığı) elde edilen verilere bütün olarak bakıldığında bireyin yakın sosyal çevresinin (aile, arkadaş gibi), bireyin (mâhkum) toplumsal uyumunda, toplumsal aidiyet duygusunu yitirmemesinde önemli bir yapısal unsur olarak önemini koruduğu görülmektedir. Bireyin (mahkûmun) içinde bağ kurduğu sosyal yakın çevrenin niteliği de, sosyal içerilme ve sosyal dişlanma süreçlerini doğrudan etkileyebilen/etkileyebilecek bir potansiyel içermektedir. Bireylerin ilişki ve iletişim halinde olduğu çevresinin, toplumsal içerilmeyi destekleyici bir potansiyeli beslemekten ziyade, sosyal dışlanmaya maruz kalanların oluşturduğu ve dışlanma süreçlerini yeniden üretecek niteliğe sahip bir çevre olduğuna ilişkin önemli ipuçları barındırdığı görülür. Aynı zamanda bu veri, dışlananların suç ve illegalite zemininde buluştuklarını ima etmektedir. Sosyal çevrenin niteliğinin bu anlamıyla, suçu önleme ve bireyin sosyal içerilme süreçlerinin işleyişi açısından da risk oluşturduğu belirtilebilir.

\subsection{Suçlu Olarak Tanımlanmanın Toplumsal İlişkilere Etkisi}

Mahkûmiyet ve suçlu olarak damgalanma durumunun bireyin toplum içindeki konumuna ilişkin etkilerini ortaya koyan verilere bakıldığında; mahkûmiyet durumunun toplumsal ilişkilerine zarar verdiğini düşünenlerin oranının \%60.5 olduğu görülmektedir. Bu oran genç suçluluğunun baskın olduğu durum dikkate alınarak değerlendirilmelidir. Toplumsal ilişkilerinin zarar gördüğünü düşünen, genç nüfusun ağırlıklı olduğu bir suçlu potansiyeli söz konusudur. Katılımcıların büyük bir kısmının hapis cezası almadan doğrudan denetimli serbestliğe geldiği düşünüldüğünde; damgalanmanın ve dışlanmanın yalnızca hapse mahkûm edilmiş olmaya dayanmadığını, bunun ötesinde yalnızca denetimli serbestlikte olmanın kendisinin bile, belirli bir damgayı ve soyutlanmayı beraberinde getirdiğini göstermektedir. Mahkûmiyet durumunun toplumsal ilişkilere zarar verici etkisi demografik özelliklerle çapraz tabloları yapıldığında; toplumsal dışlanma, soyutlanma ilişkisini yaş, toplumsal cinsiyet ve meslek gibi açılardan ele alarak irdelemek önemli verileri ortaya çıkarmaktadır. Örneğin hüküm giymenin toplumsal cinsiyet bağlamında ilişkileri etkileme durumu çapraz tablo ile değerlendirildiğinde; 
kadın suçluluk oranının düşük olmasına rağmen erkek ve kadınlarda aynı oranda sosyal ilişkilere zarar verdiğini göstermektedir (kadın, \%59.1; erkek \%60.6). Mâhkumiyet durumunun toplumsal ilişkilerine zarar verdiğini düşünenlerin içinde en yüksek kategoriyi \%66 ile 31-35 yaş grubu oluşturmakta ve bunu takiben, 26-30 yaş grubu \%64.5, 41 ve üstü yaş grubu \%62.0, 25 yaş ve altı \%50.5 oranları izlemektedir. Genel olarak oranlara bakıldığında, mâhkumiyet durumunun bütün yaş kategorileri üzerinde toplumsal ilişkiyi bozucu sonuçlar ürettiği görülmektedir. Bu yaş kategorileri için, iş piyasasına dâhil olma, aile ve sosyal statü, çocuk sahibi olma gibi beklentilerin ön planda olacağı düşünüldüğünden, toplumsal ilişkilerin zarar gördüğünün söylenmesi önemlidir. Özellikle işsiz (\%74.2), emekli (\%70.9), ev kadını (\%68.2), serbest meslek (\%62) işçi (\%61.4) kategorisinde yer alan bireylerin de sosyal ilişkilerinin bozulduğunu ifade etmesi, toplumsal ilişkilerinin sadece ekonomik ve sosyal değil çok boyutlu etkilediğinin bir göstergesidir. Sosyal dışlanma ve suç ilişkisi karmaşık ve çok yönlü değerlendirilmesi gereken bir durumdur. Aynı şekilde sosyal dışlanma potansiyel suç ve sapma nedeni olarak değerlendirilebilir. Sosyal içerilme; sosyal sermaye dolayısıyla sosyal kaynaklar ve sosyal ağ ile ilgilidir. Fırsatlara ulaşamama ve sosyal ilişkilerin yokluğu, sosyal bütünleşmede bariyer oluşturmaktadır (Kirkwood ve McNeill, 2015: 520). Bu bağlamda, Goffman'ın ele aldığı ve birçok açıdan tartıştığı damga kavramı, bireylerin toplumsal yaşam içinde farklı nedenlerden dolayı karşılaştıkları sorunları açığa çıkarmada son derece etkili bir kavram olarak karşımıza çıkmaktadır.

\section{Denetimli Serbestlik Hizmetinden Faydalanılan Zaman Diliminde Karşılaşılan Güçlükler}

\begin{tabular}{|c|c|c|}
\hline & $\mathrm{N}$ & $\%$ \\
\hline Yalnızlaştığımı düşünüyorum & 442 & 21.1 \\
\hline D1şlandiğımı düşünüyorum & 369 & 17.6 \\
\hline Sosyal yaşama uyum sorunu yaşadım & 451 & 21.5 \\
\hline Fırsatlara erişim konusunda eşit haklara sahip olmadığımı düşünüyorum & 536 & 25.6 \\
\hline İş bulamama & 583 & 27.9 \\
\hline Kalacak yer (barınma) sorunu yaşadım & 185 & 8.8 \\
\hline Herkes suçlu gözüyle bakıyordu & 498 & 23.8 \\
\hline Psikolojik sorunlar yaşadım & 734 & 35.1 \\
\hline İnsanlarla iletişim kurmakta zorlandım & 286 & 13.7 \\
\hline Yeni arkadaşlıklar kurmada güçlük yaşadım & 302 & 14.4 \\
\hline Aile ilişkilerim bozuldu & 613 & 29.3 \\
\hline Evliliğimde problemler yaşadım & 381 & 18.2 \\
\hline Ev kiralamada sorunlar yaşadım & 247 & 11.8 \\
\hline Önceden benimle görüşen kişilerin bazıları artık eskisi gibi görüşmüyorlar & 469 & 22.4 \\
\hline Çoğu zaman mahkumiyetimi saklamak zorunda kalıyorum & 1043 & 49.8 \\
\hline Kendime güven sorunu yaşıyorum & 275 & 13.1 \\
\hline Sağlıkla ilgili problemler yaşıyorum & 351 & 16.8 \\
\hline
\end{tabular}


Hüküm giymiş bireyin toplumsal yaşama tekrar dâhil olma biçimi ve karşılaştığı güçlükler sosyal dışlanma deneyim üzerine yürütülecek bir tartışmada önemli bir unsur olarak karşımıza çıkmaktadır. Söz konusu tablo incelendiğinde tecrit ya da dışlanmaya ilişkin zorlukların katılımcılar tarafından açık bir şekilde vurgulandığı görülmektedir. Sosyal dışlanmanın karşıtı olan sosyal içerilme, eğitim, mesleki eğitim, sağlık ve ulaşım hizmetlerinden yararlanma, istihdama dâhil olma, mal ve hizmetlere erişim, konut edinme, kültürel faaliyetlere katılmayı içerir. Oysa hüküm giymiş birey toplumsal yaşama tekrar dâhil olma sürecinde birçok güçlükle yüzleşmektedir. Suçlu olma damgasından dolayı önyargılara ve toplumsal dişlanmaya maruz kalan bireyler, bu negatif tutumlara maruz kalmamak için çoğunlukla $(\% 49,8)$ mahkumiyet durumunu saklama eğilimi göstermektir. Goffman (1963) damgalamayı aynı zamanda "itibarsızlaştırma” süreci olarak ele almakta ve bu süreç normalin dişında kalan, ideal birey modeline, toplumsal beklenti ve normlara dâhil edilmeyen suçlu bireyleri de içermektedir. "İtibarsızlaşma” süreci aynı zamanda benliğin örselenmesine ve bireyin sahip olduğu kimliğinin de dönüşmesine neden olmaktadır. Bireyin karşılaştığı ön yarg1 ve olumsuz tutumlar, yaşadığ1 sosyal dışlanma deneyimi sadece toplumsal bağlamda değil, bireysel bağlamda da ağır sonuçlar doğurabilmektedir. Bireylerin açık bir biçimde psikolojik destek ihtiyacı içinde olduklarını ifade etmeleri, bu durumun en önemli göstergesi olarak okunabilir. Gray’ın (2005: 948) çeşitli istatistiklerden derleyerek aktardığı gibi, özellikle hüküm giymiş bireylerin en çok duygusal ve psikolojik problem yaşadıklarını (\%66), sağlıklı ve güvenli bir evden yoksun olduklarını (\%49.7), işsiz kaldıklarını \%49 ifade ettikleri bulgular bu çalışmanın saha verileriyle de bir kez daha pekişmiştir.

Söz konusu çalışmanın örneklemi içinde çok sayıda kişinin firsatlara erişim konusunda eşit haklara sahip olmadıklarını düşünmesi de sosyal içerilmenin önündeki en önemli engellerden biridir. Sosyal dışlanma birliği tarafından (Social Exclusion Unit, 2002) yeniden suç işlemeyi ve toplumsal dişlanmayı/ içerilmeyi etkileyen 9 temel etkenin olduğunu ortaya koymuştur. Bunlar: Eğitim, işgücü, madde bağımlılığı, psikolojik ve fiziksel sağlık, tutumlar ve oto kontrol, kurumsallaşma ve yaşam becerileri, barınma, finansal destek ve borçluluk, ailevi ilişkiler olarak sıralanmıştır. Gerek özel alanda yaşanan sorunlar, gerekse kamusal alanda yaşanan güçlükler bireyin sosyal dışlanma deneyimini açığa çıkarmaktadır. Smith ve Stewart'ın (1997 anket ve yüz yüze görüşmeye dayanarak yaptıkları bir araştırmanın sonuçlarına göre; denetimli serbestlik altında olan genç bireylerin sosyal olanaklardan dışlandığı gözlemlenmiştir. Bunlar sadece işsizlik ve yoksullukla ilişkili sorunlar olmayıp, aynı zamanda eğitimi sürdürmede, ev bulmada, sosyal güvence ve sağlı̆̆a erişmede yaşanan zorluk ve problemlerle de ilgilidir. Yine yapılan çalışmalar ve denetimli serbestlik kurumunun yaptığı gözlemler 1şı̆̆ında da mahkûmiyet durumunun aile ilişkilerine zarar verdiği, bireyleri olumsuz etkilediği ve özellikle stresli ve mutsuz aile ortamında da yaşamak zorunda kaldıkları ortaya konulmuştur. Aile ilişkilerinde yaşanan zorluklar aynı zamanda güvenli ve sağlıklı konaklamadan yoksun kalmalarına neden olmaktadır (Stewart ve Stewart: 1993, Dood ve Hunter: 1992, Stewart: 1996). Sosyal dışlanmanın sosyal, ekonomik, politik ve mekânsal yönleriyle çok boyutlu bir kavram olduğu tablonun verileri 1şığında tekrar ifade edilebilir. Ekonomik boyut; işsizlik ve güvencesiz geçici işleri, düşük geliri veya istihdam ilişkilerinden dişlanmayı içerirken, sosyal boyut ise bozulan hane halkı ilişkilerini ve evsizliği, suçlu ve muhalif bir gençliği içerebilir. Politik boyutta ise; politik 
haklardan yoksun olma veya karar verme mekanizmalarında yetkisiz kılınmak, seçmen olarak kayıt dışı kalma ya da seçime yeterince katılamama, düşük düzeyde topluluk aktivitelerine katılma, yabancılaşma, politik süreçlerde güven eksiliğii, sosyal kargaşa, bozukluk gibi... Bir diğer boyut ise ayrışma, konut stoğunun azalması, yerel hizmetlerden yoksun kalma, destek ağlarının çöküşü... Sosyal dışlanmanın mekânsal boyutu ise; dezavantajlı grupların bir arada yaşaması ve bu ayrışmanın daha sonra dezavantaja dönüşmesidir. Böylece mekânsal ve bölgesel dezavantajlı duruma açık hale gelinmesi olarak tanımlanabilir. Toplum içinde bazı bireyler veya gruplar toplum içinde sahip oldukları farklılıklar ve pozisyonlarından dolayı daha çok dışlanma riskiyle karşı karşıya kalabilmektedirler. Örneğin, etnik, dinsel, dilsel farklıklar sosyal dışlanmaya neden olabildiği gibi bazen yaşam tarzı, kişisel ve sosyal değerler ve karakterlerdeki farklılıklar da buna neden olabilir (Percy-Smith, 2000: 9-11). Sosyal dışlamanın çok boyutlu ve geniş bir bağlamda ele alınması; toplumsal ayrışmanın öznesi olan bireylerin de çok farklı alanlarda sorun yaşamasını beraberinde getirmektir. Bu sorunlar makro düzeyden (ekonomik yapı, politik, hukuki yapı), mikro düzeye kadar (aile içi ilişkiler, komşuluk, duygusal bağlar) farklı sorunları içebilmektedir.

Toplumsal dışlanmanın veya içerilmenin en önemli göstergelerinden biri de istihdama dâhil olma/olamama biçimidir. Aynı zamanda teorik tartışmalar ve ampirik veriler suç, ekonomik koşullar ve emek piyasası arasında ilişki olduğunu ortaya koymuştur. Düzenli ve ücretli bir işe sahip olmanın suçu önlemede önemli rol oynadığı da tartışılmaktadır (Hale, 2013: 289). Çalışma kapsamında anket uygulanan bireylerin gelir dağılımı ve şu anda yaptıkları işler birlikte incelendiğinde; hükümlülerin daha çok enformel ya da kayıt dışı çalışma koşulları içerisinde var olmaya çalıştıkları görülmektedir. Örneklemin \% 70'ini 1500 TL ve altı gelire sahip bireyler oluşturmakta ve bunların da daha çok serbest meslek, işçi, kendi işinin sahibi ve işsiz olduğu gözlemlenmektedir. Kendi işinin sahibi olması, kendi hesabına çalışma yine, sosyal güvencelerden yararlanamama ya da kısmen yararlanmayı içerdiğinden, standart dışı çalışmanın bir göstergesi olarak kabul edilebilir (Sapancalı, 2005). Bunun diğer bir anlamı, geçici, düzensiz, gündelik, düşük ücretli çalışma koşullarına maruz kalma ve sosyal güvencelerden yoksun bırakılmaktır. Aynı zamanda bu veriler doğrudan ekonomik yaşam, suç ve sosyal dışlanma arasındaki ilişkiyi gündeme getirerek, dışlanmanın bileşenlerinin neler olduğunu tartışmamızı gerekli kılmaktadır. Dışlanmanın 3 temel bileşenin olduğu ve bunlardan ilkinin görecelik ile ilişkili olduğu ifade edilmektedir. Sosyal dışlanmayı ortaya çıkaran koşullar ve dışlanmanın hangi toplumsal, kültürel ekonomik alanları içerdiği farklı kişilere göre değişebilmekte veya kavramın farklı tanımları yapılabilmektedir. Dışlanmışlığın ve yoksunluğun farklı kaynaklara dayanması, sosyal dışlanmanın ikinci unsurunu oluşturmaktadır. Yukarıda da belirtildiği gibi sosyal dışlanma ekonomik, siyasal, kültürel, politik gibi çok farklı süreç ve kaynakların yoksunluğu ile ilgili olabilmekte ya da bireyler bu gibi temel alanlarda farklı kurumlar aracılığıyla dışlanmaya maruz kalabilmektedir. Bireyler, pazar ekonomisinden uzaklaşabilir, bankalar kredi vermeyebilir, sosyal güvenceden yoksun kalabilir, işveren, kurumsal düzeyde veya iş̧̧iler aracillğıyla dışlanmaya maruz kalabilir. Dışlanma aynı zamanda bireylerin beklentilerinin ve gereksinimlerinin karşılayamaması, toplumsal bağların zayıflaması ile ilgili dinamik bir süreçtir. Bireyler bu süreçte sadece işsiz veya gelirsiz olmalarından dolayı dışlanmaz aynı zamanda geleceğe yönelik umutsuz veya çok az beklentisi olmasından dolayı da dışlanır. Bu umutsuzluk bireyin çocukları için taşıdığı kaygıyı da içerir. Dolaysıyla dışlanma kuşaklar boyu sürebilir (Atkinson, 1998: 14, Silver ve Miller, 2003: 8). Hale ve Fitz ( 2007: 142) ise sosyal dışlanmanın birleşenlerinin neler olduğunu tartışırken ilk olarak işgücü piyasasına vurgu yapmaktadır. 
İkinci olarak ekonomik açıdan dışlanmanın yalnızca işgücü piyasası ile ele alınamayacağını, tüketimden de dışlanmanın önemli olduğunu belirtmektedirler. Tüketim, bireyin içinde bulunduğu gelir grubundan ziyade kendisine referans olarak aldığı gelir grubunun tüketim kalıplarına ulaşamaması olarak da tanımlanmaktadır. Böylece gelir dağılımı yanında tüketime de dikkat çekilmektedir. Üçüncü olarak ise ceza politikalarının doğrudan sosyal dışlanma ile olan ilgisine vurgu yapmaktadırlar (Hale ve Fitz, 2007: 142). Veriler toplumsal içerilme konusunda gelir, sağlık, eğitim, barınma vb. temel ihtiyaçların karşılanmasının yanında, güvence ve istikrar içeren çalışma koşullarındaki iyileştirmelerin önemini ortaya koymaktadır.

Mahkumiyet durumunun sahip olduğu konumunu ve işini etkileyip etkilemediğine ilişkin veriler bize iş piyasasına içerilme ve sosyal bütünleşme süreçlerini doğrudan etkilediğini de göstermektir. Bu bağlamda söz konusu çalışma kapsamında görüşülen bireylerin \% 52.8'i mahkumiyet durumunun işin kaybedilmesi üzerinde doğrudan etkisi olduğunu ifade etmiştir. "Hükümlü” etiketi altında mevcut haliyle damgası görünür olan bireylerin işini kaybetmesi, damganın kendi başına sosyal dışlanma sürecini besleyen bir durum olduğunu da göstermektedir.. Örneğin “iş bulmada zorluk yaşadınız mı” sorusuna \%57.5 oranında hayır denilmesi, olumlu istihdam koşullarının ve tutumlarının göstergesi değildir. Veriler ve alana ilişkin gözlemlerden yola çıkarak şu ifade edebilir ki; bu bireyler, hem çalışırken hem de bir iş arama aşamasında mahkûmiyetlerini saklama eğilimi göstermektedir. Bununla birlikte hayır cevabı, katılımcıların gelir durumunu ve yaş dağılımını ile ilişkilendirildiğinde, iş piyasasına dâhil olamayan, dolayısıyla çalışmanın karşılığında yeterli bir gelir elde edemeyen ve aileleri ile birlikte yaşayan bireylerin sayısının (25 yaş ve altı) fazlalığı ile açıklamak mümkündür. Gelir durumu ve işsizlik oranı bağlamında katılımcıların, bu soruya hayır yanıtını verme nedenleri bu çerçevede anlaşılabilir.

\begin{tabular}{lcc}
\hline İş Bulmada Karşılaşılan Zorluklar & $\mathrm{n}$ & $\%$ \\
\hline Mahkumiyet durumumdan dolayı iş alımında isteksiz davrandılar & 567 & 58.3 \\
$\begin{array}{l}\text { Mahkumiyet durumumdan dolayı çalışma hayatından uzun süre ayrı kaldığım için zorluk } \\
\text { yaşadım }\end{array}$ & 21.8 & 22.4 \\
$\begin{array}{l}\text { Bana yardım edecek kişiler (aile, arkadaş, tanıdık vb.) bulunmadığı için iş bulmada zorluk } \\
\text { yaşadım }\end{array}$ & 187 & 7.3 \\
$\begin{array}{l}\text { Denetimli serbestliğin getirdiği yükümlülüklerin yoğunluğundan dolayı (eğitim programları, } \\
\text { yoğun gözetim, imza zorunluluğu, kamu hizmeti vb.) iş bulmada zorluk yaşadım }\end{array}$ & 505 & 19.7 \\
İş deneyimi ve bireysel beceri yetersizliği & 62 & 2.4 \\
\hline
\end{tabular}

Görüldüğü gibi, hükümlüler açısından ilk büyük zorluk, mahkûmiyet durumlarından dolayı işverenlerin gönülsüzlüğüdür; iş yaşamından ayrı kalmaları ve denetimli serbestlik hizmetinin yoğun programı iş bulmada karşılaşılan zorluklar olarak belirginleşmektedir. İş piyasasına dâhil olmama/olamama, çalışma yaşamı içerisinde bilgi ve beceri edinme bakımından biriktirebileceği deneyimlerden, iş ilişsisi kurabileceği sosyal ağlardan yoksun olmayı da beraberinde getirmektedir. Bunun diğer bir anlamı iş, gelir, sosyal güvencelerden yoksun olma sorunuyla karşı karşıya kalmaktır. Veriler, mahkûmiyet durumunun, işe alım sürecinde ve her bireyin iş ve sosyal ilişki ağı içerisindeki etkileşim dinamiği içerisinde bir "risk" olarak belirginleştiğini ortaya koymaktadır. Damganın görünürlüğü (mahkûmiyet durumunun bilinmesi) ki, Gofmann’ın (2014), işaret ettiği gibi, bireyin 
diğerleriyle girdiği etkileşim sürecinde, basit bir teması bile damgasını bilinir hale getirebilir. Burada mahkûmiyet durumunun, sosyal etkileşim dinamiği içerisinde diğerleri (iş ilişkisinde bulundukları hükümlü olmayan bireyler) tarafından nasıl bir bakış açısıyla değerlendirilmeye alındığı da önemlidir.

Dolayısıyla çalışma ve bundan elde edilen bireysel, sosyal ve ekonomik kazanımlar, toplumsal sürekliliği sağlayan değerlerin, bireyler (mahkûmlar) açısından yeniden anlam kazanması, sosyal dışlanmaya maruz kalan bireylerin, toplumla aralarında çözülen bağın yeniden kurulması konusunda önemli rol oynayacaktır. Örneğin denetimli serbestlik aşamasında nasıl geçindikleri ve şu anda yaptıkları işleri nasıl buldukları ile ilgili soruya büyük oranda aile, yakın çevre ve arkadaşlık ilişkileri yanıtının verilmesi de bu anlamda önemlidir. Kurumsal ve profesyonel destek aramak ya da bireysel ilişkilerle oluşturulmuş firsatlar söz konusu değildir. Bireyler hâlâ geleneksel, enformel ilişki ağları ve desteklerle yeniden topluma katılmaya çalışmaktadırlar. Bu durum, ilişki ağlarının ağırlıklı olarak geleneksel yöntemlerle işlediği, tam anlamda kurumsallaşmanın olmadığı bir toplumsal durumun ifadesidir.

\section{SONUÇ}

Denetimli serbestlik aşamasına gelmiş hükümlü birey; suçu kesinleşmiş, belli yaptırımlar ve cezalar sonrası sosyal yaşama dahil olmuş ve gündelik yaşamını toplum içinde sürdüren birey anlamına gelmektedir. $\mathrm{Bu}$ bireyler, hükümlü olarak etiketlenmenin dezavantajlı boyutlarının ve bu kimliğin yarattığı önyargılı davranışların öznesi olabilmektedir. Sosyal dışlanmanın çok farklı dinamikleri olduğu ve suçun da bu durumun hem bir nedeni hem de sonucu olabileceği sosyolojik olarak tartışılmaktadır. Aynı zamanda sosyolojik olarak dışlanmayı besleyen süreçlerin tek bir boyutu olmadığı, ekonomik, sosyal, hukuki, politik v.b. alanlarla ilişkili çok boyutlu olarak tartışılmaktadır. Bu araştırma kapsamında veriler bize, mahkum olarak etiketlenen bireyin toplumsal yaşam içinde çok farklı sorunlarla karşılaştığını, gerek ekonomik yaşamdan gerekse sosyal çevreden dışlandığını ortaya koymaktadır. Genel olarak suçlu olarak damgalanmış ve ceza almış birey, sosyal çevresini, ailesini, işini kaybetmekle karşı karşıyadır. Cezası bittiğinde ise bireyin, özel ve mahrem ilişkilerinden sosyal çevresine, iş yaşamından boş zaman değerlendirmesine kadar birçok alanda zorluklarla karşı karşıyadır. Aile ve yakın iliş̧kilere zarar veren mahkûmiyet durumunun, yalnızlaşmaya ve psikolojik sorunlara neden olduğu ortaya çıkmıştır. Çoğunlukla sosyal ilişkilerde ve iş ortamında mahkûmiyetin gizlendiği ve özellikle iş ve ekonomik yaşamda yaşadıkları dışlanmanın özel ilişkilerine zarar verdiği görülmüştür. Mahkûmiyet durumunun evlilik ilişkisi ve ebeveyn ilişkilerine olumsuz anlamda yansıdığı söylenebilir. Ancak tüm bu sorunlara rağmen hükümlü bireylerin psikolojik, ekonomik anlamlarda yine de en fazla aile ve yakın çevreden destek aldıkları gözlenmiştir. Bir çok sorunu çözmede aile ve yakın arkadaş çevresine başvurduğunu söyleyen bireylerin; kurumsal, profesyonel destek ve yardımdan uzak oldukları dikkat çekmektedir. Kurumsal destekten uzak olmaları; sosyal dışlanmanın karşııı olan sosyal içerilme süreçlerini sekteye uğratarak, bireyin kendini soyutlamasına, toplumla bütünleşememesine, yurttaşlık bilincinin yitirilmesine ve tekrar suça yönelmesine neden olabilmektedir. $\mathrm{Bu}$ bağlamda bireyin sosyal dışlanmanın suça yönelten etkilerinden korunması, toplumsal bütünleşmesinin sağlanması ve toplumla çözülen bağlarının yeniden güçlendirilmesi için sosyal içerilmeyi sağlayacak kurumsal, profesyonel ve bilimsel çalışmalara dayalı politika ve uygulamalara duyulan ihtiyaç ortadadır. 
Hüküm giymeden önceki gelir durumları ile mevcut gelir durumlarının karşılaştırıldığı verilerden hareketle, mahkumiyetle birlikte gelir durumlarında anlamlı bir değişiklik olmadığı söylenebilir. Bu durumda suçluluk ile yoksulluğun içiçe olduğunu ifade etmek mümkündür. Birey suç işlemeden önce de yoksullukla başa çıkmaya çalışan bir konumda olduğuna göre, suçluluk ve sınıfsal/sınıf altı durumu ve ilişkisi derinlemesine irdelenmeye ve araştırılmaya dair özel bir dikkati hak etmektedir. Mahkûmiyet durumuyla kendisi ile olan ilişkisi ve kendisine ilişkin algısı değişen ve yeni kimliğiyle yeniden sosyal hayata katılan hükümlü, toplumun kendisi ile ilgili algısının değiştiğini düşünmekte ve deneyimlemektedir. Araştırma bulguları değişik çapraz özellikler dikkate alınarak analiz edildiğinde hükümlülerin sosyal hayata bu yeni kimlikleriyle dahil olma aşamasında, bu durumun yaratacağı sıkıntıları aşmak için çoğunlukla mahkumiyetlerini gizlediklerini de ortaya çıkarmıştır.

Araştırma verileri bu anlamda ele alındığında iş yaşamı ve istihdamla ilgili sorunların çözülmesi gereken temel mesele olarak ortada durması bu durumun onaylanması gibidir. Bu durum hükümlüler açısından, yoksulluk, iş piyasasının dışında kalmak, sosyal ve kültürel alandan dışlanma ve politik alandan dışlanmaya kadar bir çok alanda zincirleme etkilidir. Bu bağlamdaki dışlanma bireyin bütün toplumsal kurumlarla, değerlerle ve normlarla ilişkisinin bozulmasını ifade eder. Çünkü ekonomik alandan dışlanma, mekânsal, sosyal dışlanmayı hızlandırmaktan, yurttaşlık bilincinin yitimine kadar olumsuz sonuçlar üretmektedir. Araştırma verilerine baktığımızda, denetimli serbestlikten faydalanan bireylerin büyük çoğunluğunun genç nüfustan oluşması ve suç oranlarına bakıldığında madde bağımlılığının yüksek olması, ayrıca en önemli sorunun istihdam olması ve sosyal, psikolojik desteğe olan gereksinimin net biçimde ifade edilmesi, kurumsal desteğin ne denli önemli olduğunu bir kez daha ortaya koymaktadır.

\section{KAYNAKÇA}

Atkinson, Tony (1998), “Chapter One: Social Exclusion, Poverty and Unemployment”, Exclusion, Employment and Opportunity, Atkinson A.B., Hill J., (Edt.) Centre for Analysis of Social Exclusion, London School of Economics (CASE), No: 4, London.

Bancroft, Angus - Wilson, Sarah- Cunningham, Burley Sarah - Backet, Milburn Kathryn- Masters, Hugh (2004), Parental Drug and Alcohol Misuse: Resilience and Transition Among Young People, York Publishing, Edinburgh.

Becker, S. Hovard (2013), Hariciler (Outsiders), Bir Sapkınlık Sosyolojisi Çalışması, Çev. Levent Ünsald1Şerife Geniş, Heretik Yayınları, İstanbul.

Bengtsson, Tea Torbenfeldt (2016), "Performing Hypermasculinity: Experiences with Confined Young Offenders", Men and Masculinities, Vol. 19, No. 4, (410-428).

De Haan, Arjan (2000), "Social exclusion: Enriching the Understanding of Deprivation”, Studies in Social and Political Thought, Vol. 2, No. 2, (22-40).

Department of Human Services, Victoria, Australia. (2000) "What is stigma", Available: http://hna.ffh.vic.gov.au/acmh/mh/mental_illness/stigma.htm.

Dood, Tricia - Hunter, Paul (1992), The National Prison Survey, HMSO, London. 
Durkheim, Emile (1960), The Division of Labour in Society (1863), Free Press, New York.

Durkheim, Emile (1995), Toplumbilimsel Yöntemin Kuralları, Çev. Cemal Bali Akal, Engin Yayıncılık, İstanbul.

European Monitoring Centre for Drugs and Drug Addiction report (2008), Office for Official Publications of the European Communities, Luxembourg.

Gray, Patricia (2005), "The Politics of Risk and Young Offenders Expreiences of Social Exlusion and Restorative Justice”, British Journal of Criminology, Vol. 45, No: 6, (938-957).

Goffman, Erving (1961), Asylums: Essays On The Social Situation Of Mental Patients And Other Inmates, NY: Anchor Books, Garden City.

Goffman, Erving (1963), Stigma, Penguin, London. (Goffman, Erving (2014), Damga, Yay. Haz. Levent Ünsald1, Heretik Yayınları, Ankara).

Hale, Chris (2013), "Economic Marginalization, Social Exlusion and Crime", Criminology, Hale Chris, Hayward K., Wahidin A., Wincup E., (Edt.), Oxford University Press, Oxford.

Hale, Chris- FitzGerald, Marian (2007), "Social Exclusion and Crime", Multidisciplinary Handbook of Social Exclusion Research, Abrams, D., Christian, J., Gordon, D., (Edt.), John Wiley \& Sons., West Sussex, (137-158).

Harding, J. David (2003), "Jean Valjean's Dilemma: The Management of Exconvict Identity in the Search for Employment”, Deviant Behavior, Vol. 24 (571-95).

Kirkwood Steve- McNeill Fergus, (2015) "Integration and reintegration: Comparing Pathways to Citizenship Through Asylum and Criminal Justice”, Criminology \& Criminal Justice (CCJ), Vol. 15, No. 5, (511526).

Krienert, Jessie L. (2003), "Masculinity and Crime: A Quantitative Exploration of Messerschmidt's Hypothesis", Electronic Journal of Sociology, Vo. 7, No. 2, (1-30).

LeBel, Thomas P. (2008), "Perceptions of and Responses to Stigma”, Sociology Compass, Vol. 2, No. 2, (409432).

Lemert, Edwin (1969), "Primary and Secondary Deviation, Crime and Social Process”, Harper and Row, New York.

Merton, Robert K. (1938), "Social Structure and Anomie”, American Sociological Review, Vol. 3, No. 5, (672682).

Peace, Robin (2001), “Social Exclusion: A Concept In Need Of Definition?”, Social Policy Journal of New Zealand, Issue:16, (17-36).

Percy, Smith Janie (2000), "Introduction: The Contours of Social Exclusion”, Policy Responses to Social Exclusion: Towards Inclusion, Percy-Smith, Janie (Edt.), Open University Press, BuckinghamPhiladelphia. 
Pope, Whitney (2008), “Emile Durkheim”, Sosyolojik Düşüncede İz Bırakanlar, Rob Stones (Yay. Haz.), Çev. Nihat Z. Erdoğan, Bağlam Yayınları, İstanbul, (78-90).

Report by the Social Exclusion Unit (2002), "Reducing Re-Offending By Ex-Prisoners.

Sapancalı, Faruk ( 2005), “AB’nde Sosyal Dışlanma Sorunu ve Mücadele Yöntemleri”, Çalışma ve Toplum, Say1: 3, (51-106).

Schneider, Andreas - McKim, Wayne (2003), "Stigmatization Versus Self-Stigmatization of Probationers", Journal of Offender Rehabilitation, Vol. 38, No. 1, (19-31).

Silver, Hilary (1994a), “Three Paradigms”, International Labour Review, Vol. 133, No. 5-6, (531-578).

Silver, Hilary (1994b), "Social exclusion and Social Solidarity: Three paradigms", Institute for Labour Studies, Geneva.

Silver Hilary - Miller, S. Mike. (2003), "Social Exclusion, The European Approach to Social Disadvantage", Poverty \& Race, Vol. 2, No. 2 , (1-24).

Smith David - Stewart, John (1997), "Probation and Social Exclusion", Social Policy Administration, Vol. 31, No. 5, (96-115).

Stewart, Gill (1996), "Housing", Beyond Offending Behaviour, Drakeford Mark., Vanstone Mark (Edt), Arena, Aldershot.

Stewart, Gill - Stewart, John (1993), Social Circumstances of younger Offenders Under Probation Supervision, ACOP, Wakefield.

Stiker, Henri Jacques (2011), "Yeni Özürlü Beden Algısı", Bedenin Tarihi-2, Corbin A., Courtine J. J., Vigarello G., (Edt.), Çev. Saadet Özen, Yapı Kredi Yayınları, İstanbul, (219-235).

Tolan, Barlas (1981), Çăgdaș Toplumun Bunalımı: Anomi ve Yabancılașma, A.İ.T.İ.A., Gazetecilik ve Halkla İlişkiler Yayınları, Ankara.

Ünal , Halime (2012), “Sapma ve Suç”, Sosyolojiye Giriş, Tuna M. (Edt.), Detay Yayıncılık, Ankara, (326-348).

Yavuz, Hakan A. (2016), “Türkiye'de Denetimli Serbestlik Mümkün Müdür? Dünü, Bugünü ve Yarınıyla Türk Ceza Adalet Sisteminde Denetimli Serbestlik", Türkiye'de Denetimli Serbestlik 10. Yll Uluslararası Sempozyumu Bildiri Kitabl, Deniz Özyörük (Edt.), Adalet Bakanlığı Ceza Ve Tevkifevleri Genel Müdürlüğ̈̈, Atalay Matbası, Ankara.

Young, Jock (1999), The Exclusive Society: Social Exclusion, Crime and Differencein Late Modernity, Sage, London. 
"Hükümlü" Olmanın Sosyal Tezahürleri: Sosyal Dışlanma, Damga Ve Suç Meral TIMURTURKAN, Gönül DEMEZ, Elife KART, Cihan ERTAN, Selim CANKURTARAN, Salih AKTIN 